\title{
APLIKASI KITOSAN SEBAGAI ZAT ANTIBAKTERI PADA KAIN POLIESTER-SELULOSA DENGAN CARA MODIFIKASI GUGUS POLIESTER-SELULOSA
}

\author{
ANCHORING CHITOSAN AS AN ANTIBACTERIAL AGENT ONTO \\ POLYESTER-CELLULOSE FABRICS BY MEANS OF MODIFYING OF \\ POLYESTER-CELLULOSE CHEMICAL STRUCTURES
}

\author{
Wiwin Winiati, Wulan Septiani, Cica Kasipah, Arif Wibi Sana \\ Balai Besar Tekstil, Jalan Jenderal Ahmad Yani No. 390 Bandung \\ E-mail: texirdti@bdg.centrin.net.id
}

Tanggal diterima: 12 Juni 2017, direvisi: 9 Januari 2018, disetujui terbit: 11 Januari 2018

\begin{abstract}
ABSTRAK
Pada penelitian terdahulu, aplikasi kitosan pada kain poliester-selulosa (kapas/rayon) dengan teknik perendaman disertai proses untuk oksidasi selulosa dengan periodat yang menghasilkan gugus aldehida, telah menghasilkan kain poliester-selulosa antibakteri. Pada penelitian ini aplikasi kitosan pada kain poliester-selulosa dilakukan melalui 2 tahap proses modifikasi gugus poliester-selulosa yaitu proses untuk menempelkan gugus amina dari alkilamina (dodesilamina) pada serat poliester dilanjutkan dengan proses untuk oksidasi selulosa dengan periodat bersamaan dengan menempelkan kitosan pada serat poliester-selulosa termodifikasi. Diketahui bahwa pada teknik padding diperlukan waktu yang lebih singkat dan diperlukan larutan padding yang lebih sedikit dari pada larutan untuk cara perendaman, pada penelitian ini proses penempelan dilakukan dengan teknik padding 2 tahap. Digunakan kain poliester-selulosa yang tidak berwarna (kain grey) dan yang telah diberi warna yaitu hijau angkatan darat (AD) dan kain loreng. Hasil penelitian menunjukkan telah dihasilkan kain poliester-selulosa yang mempunyai sifat antibakteri. Sifat antibakteri yang diperoleh mempunyai durabilitas (ketahanan) terhadap pencucian yang baik yaitu setelah pencucian berulang setara 25 kali pencucian rumah tangga, ketahanan terhadap bakteri Staphylococcus aureus hampir tidak berubah yaitu turun 0-20\%, sedangkan terhadap bakteri Escherichia coli ketahanan bakteri turun sebanyak 20-40\%. Penempelan kitosan dengan cara padding 2 tahap tersebut pada kain poliester-kapas/rayon berwarna, walaupun memberikan peningkatan atau penurunan nilai K/S tetapi secara visual tidak mengakibatkan perubahan ketuaan warna yang signifikan.
\end{abstract}

Kata kunci: antibakteri, kitosan, padding, polyester-selulosa

\begin{abstract}
Exhaust method for anchoring chitosan onto polyester-cellulose fabrics has successfully produced antibacterial polyester-cellulose fabrics. As time and amount of solution needed in padding method were less than in exhaus method, in this research anchoring of chitosan onto polyester-cellulose fabrics was done using padding method. Two steps of padding method was done, the first step of padding for anchoring alkylamine onto polyester structure continued with the second step of padding for oxidizing cellulose structure with sodium periodate simultanneously with anchoring chitosan onto the modified polyester-cellulose structures. Grey and after dyed/printed of polyester-cotton/rayon fabrics were used. By means of the two steps of padding method, the polyester-cellulose fabrics having an antibacterial properties have been yielded. The achievement antibacterial properties have a good durability of washing, almost no change (decrease 0-20\%) in resistance to staphylococcus aureus bacteria whereas resistance to escherichia coli bacteria 20-40\% decreased after washing durabily tested. Padding method for anchoring of chitosan onto colored polyester-cellulose fabrics resulted no significant decreasing to the value/depth of fabrics colors.
\end{abstract}

Keywords: antibacteri, chitosan, padding, polyester-cellulose

\section{PENDAHULUAN}

Kitosan adalah biopolimer alam yang berupa polisakarida linier dari $\beta-1,4-\mathrm{D}-$ glukosamina. Dengan adanya kandungan gugus amina primer yang bersifat kationik, pada $\mathrm{pH}<6,5$ kitosan yang berada dalam larutan akan bermuatan positif sehingga kitosan merupakan polimer polikationik. $^{1,2}$ Permukaan luar tubuh mikroba 
bermuatan positif. Hal ini menyebabkan kitosan mempunyai sifat menghambat aktifitas mikroba (anti bacterial activity). Dari penelitian yang telah dilakukan ternyata kitosan juga bersifat antivirus dan antijamur, non toksik dan non alergik. ${ }^{3,4,5}$

Kain poliester-kapas dan poliester-rayon banyak digunakan baik sebagai kain sandang maupun sebagai kain non-sandang. Kain poliesterkapas dan poliester-rayon sebagai kain sandang, banyak digunakan sebagai kain untuk pakaian seragam, diantaranya sebagai seragam karyawan dan juga seragam militer. Kapas, rayon dan poliester merupakan media yang baik untuk tumbuh kembangnya bakteri, hal ini diperbesar oleh adanya keringat dari pemakainya sehingga dapat menimbulkan bau, ${ }^{6}$ oleh karena itu pakaian tersebut perlu selalu dicuci setiap setelah satu kali dipakai. Khususnya bagi pekerja yang bertugas dilapangan diinginkan pakaian seragam yang dapat dipakai berhari-hari tanpa perlu dicuci dan tidak menimbulkan bau. Hal ini akan dapat dipenuhi apabila kain tersebut dibubuhi zat antibakteri yang dapat melekat kuat pada serat tekstil. ${ }^{7-10}$

Penempelan kitosan pada kain kapas (selulosa) telah dilakukan oleh Chattopadhyay, ${ }^{11}$ kitosan awal dengan ukuran partikel 4014 nm dan nano-kitosan dengan ukuran partikel 468 nm$110 \mathrm{~nm}$ yang dilarutkan pada asam asetat, diaplikasikan pada kain kapas dengan teknik paddry-cure. Pada teknik pad-dry-cure, kain dicelupkan pada $1 \mathrm{~g} / \mathrm{L}$ larutan kitosan dalam bak padding kemudian kain diperas melalui roller (padding mangle) untuk mendapatkan WPU (wetpick-up) $70 \%$ selanjutnya difiksasi dalam mesin curring pada $170^{\circ} \mathrm{C}$. Pengamatan untuk sifat antibakteri menunjukkan bahwa penurunan ukuran partikel kitosan telah meningkatkan sifat antibakteri, tetapi pada penelitian ini tidak dilakukan uji durabiliti (ketahanan melekat) kitosan pada kain. Penempelkan kitosan pada kapas telah dilakukan pula oleh Ramadan, M. A., ${ }^{12}$, kitosan ditempelkan melalui reaksi yang ditunjukkan pada Gambar 1, dengan teknik perendaman (ekshaus). $\begin{array}{lllll}\text { Oksidasi selulosa dengan } & \mathrm{KIO}_{4} & \text { atau } & \mathrm{NaIO}_{4}\end{array}$ (kalium/natrium metaperiodat) menyebabkan terjadinya oksidasi pada gugus hidroksil C2 dan C3 yang menghasilkan gugus 2,3-dialdehida. Gugusgugus dialdehida tersebut dapat berikatan dengan gugus amino pada kitosan membentuk ikatan dimana kitosan terfiksasi pada permukaan kapas, uji durabiliti belum dilakukan. ${ }^{12}$ Aplikasi kitosan sebagai zat antibakteri pada kain kapas telah dilakukan juga oleh Winiati. W, ${ }^{13}$ yaitu fiksasi kitosan pada kain kapas dengan cara perendaman/exhaus menurut reaksi yang ditunjukkan pada Gambar 1, yang dilakukan dalam skala laboratorium dilanjutkan dalam skala pilot di industri tekstil. Dari percobaan dalam skala laboratorium maupun dalam skala pilot di industri diperoleh bahwa proses fiksasi dengan cara exhaus telah berhasil menempelkan kitosan pada kain kapas, dan kitosan dengan berat molekul yang lebih rendah memberikan hasil fiksasi yang lebih baik. Uji durabiliti dengan cara pencucian berulang yang setara dengan $15 \mathrm{x}$ pencucian rumah tangga terhadap kain yang dihasilkan menunjukkan ketahanan bakteri hanya berkurang 1-2\%. Dengan cara tersebut diperoleh kain kapas yang hampir $100 \%$ antibakteri yang diperuntukkan sebagai bedsheet dan pakaian para medis. Selanjutnya, Winiati. $\mathrm{W},{ }^{14}$ mengaplikasikan fiksasi kitosan pada kain kapas dengan cara perendaman/exhaus menurut reaksi yang ditunjukkan pada Gambar 1 tersebut, pada kain campuran poliester-kapas dan kain campuran poliester-rayon. Hasil penelitian menunjukkan kitosan dapat berikatan dengan kapas/rayon maupun dengan poliester. Cara tersebut juga dicoba pada kain hijau AD (Angkatan Darat) dan kain loreng yang terbuat dari poliesterrayon dan poliester-kapas.

Knittel. D, ${ }^{15}$ mencoba menempelkan kitosan pada serat poliester dengan cara modifikasi permukaan poliester menggunakan dodesilamine (alkilamine) melalui teknik pencelupan dispersi, hingga diperoleh gugus amino pada permukaan poliester. Selanjutnya diberikan larutan kitosan dengan bahan pengikat senyawa triazine, hingga diperoleh penempelan kitosan pada serat poliester, hal ini dijelaskan pada Gambar 2. ${ }^{15}$

Pembubuhan kitosan pada kain dengan teknik perendaman yang telah dilakukan,,13,14 menggunakan larutan kitosan 1\% sebanyak 20-40 kali berat kain (vlot 20-40), dan larutan kitosan akan dibuang setelah proses selesai, larutan yang dibuang ini ternyata masih mengandung kitosan sekitar $40 \%$ dari jumlah awal. Selain itu, waktu perendaman yang dilakukan cukup lama yaitu 90 menit pada temperatur $80^{\circ} \mathrm{C}$. Sebagai alternatif, pembubuhan kitosan pada kain dapat dilakukan dengan teknik pad-dry-cure. Pada teknik pad-drycure, bila dilakukan untuk mendapatkan WPU (wetpick-up) hingga $100 \%$ akan diperlukan jumlah larutan kitosan yang sama dengan berat kain. Rreaksi antara kitosan dengan serat/kain akan terjadi pada proses curring, yaitu pada temperatur 120-180 ${ }^{\circ} \mathrm{C}$ selama 3-5 menit. Dalam hal ini bila proses pembubuhan kitosan pada kain dialihkan dari teknik perendaman ke teknik pad-dry-cure akan diperoleh waktu yang lebih singkat dan terhindar dari terbuangnya sisa larutan kitosan. 


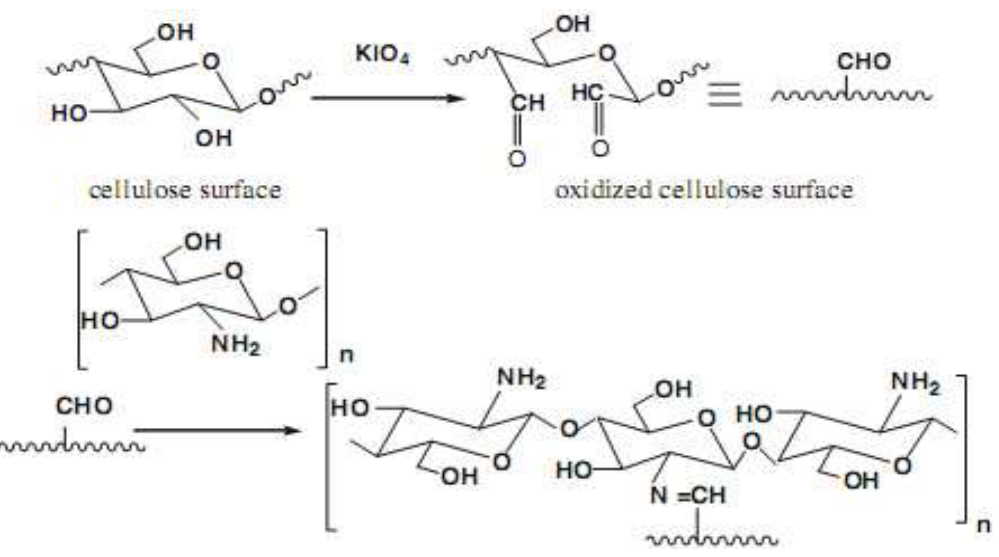

Gambar 1. Reaksi fiksasi kitosan pada selulosa ${ }^{12}$

a

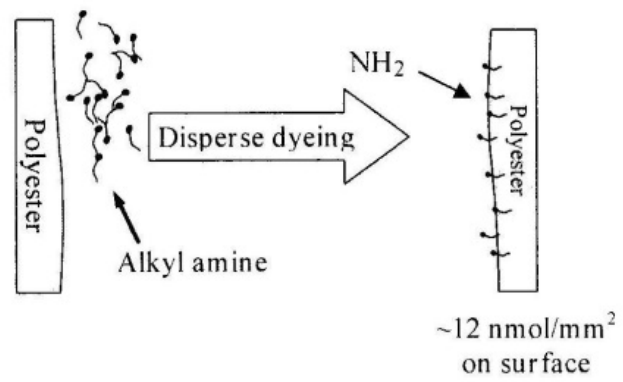

b

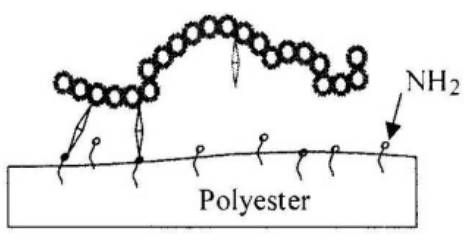

B Biopolymer $\quad A$ Anchor

Gambar 2. Penempelan kitosan cara modifikasi poliester ${ }^{15}$

Pada penelitian ini dilakukan penempelan kitosan sebagai zat antibakteri pada kain poliesterselulosa(kapas/rayon), untuk menempelkan kitosan pada poliester dilakukan modifikasi permukaan poliester menggunakan alkilamina, sedangkan untuk menempelkan kitosan pada kapas/rayon dilakukan dengan menambahkan oksidator natrium periodat. Proses penempelan dilakukan dengan teknik pad-dry-cure, digunakan kain poliesterkapas/rayon yang tidak berwarna (kain grey warna putih) dan yang telah diberi warna yaitu hijau $\mathrm{AD}$ dan loreng. Penelitian dilakukan dalam skala laboratorium. Keberhasilan penempelan kitosan pada kain diamati dengan melakukan pengujian dengan FTIR, uji antibahteri dan uji durabiliti melalui pencucian berulang.

\section{METODE}

\section{Bahan}

Kain poliester-rayon yaitu, kain hijau $\mathrm{AD}$ dengan berat $0,361 \mathrm{~kg} / \mathrm{m}^{2}$, kain poliester-kapas yaitu kain yang belum diberi warna (kain grey warna putih) dan kain loreng dengan berat 0,364 $\mathrm{kg} / \mathrm{m}^{2}$, serta bahan kimia grade teknis diperoleh dari pasaran, kitosan grade industri diperoleh dari PT. Biotech Surindo Cirebon. Bahan kimia grade p.a diperoleh dari Merck.

\section{Peralatan}

Peralatan yang digunakan meliputi mesin padding-drying-curring skala laboratorium, microwave oven.

\section{Prosedur Kerja}

- Potong kain sesuai kebutuhan

- Buat larutan kitosan 0,5\%, 1\% dan 2\% (b/v) dalam asam asetat $1 \%(\mathrm{v} / \mathrm{v})$ untuk kitosan BM sekitar 60.000 Da

- Penempelan kitosan pada kain poliester-selulosa dilakukan dengan cara padding melalui 2 tahapan proses padding, padding tahap pertama untuk modifikasi poliester, dilanjutkan padding tahap kedua untuk modifikasi selulosa bersamaan dengan fiksasi kitosan pada poliester dan kapas yang telah dimodifikasi.

- Tahap modifikasi poliester:

- buat larutan isopropanol-air 1:1 (v/v) sebanyak 1 liter, larutkan 5 g dodecylamine ke dalam larutan tersebut. Pada mesin padding, impregnasi kain pada larutan dodecylamine tersebut, lalu peras diantara 2 rol pemeras untuk mendapatkan wet-pick-up (WPU) $100 \%$ Predrying pada $80{ }^{\circ} \mathrm{C}$ selama 5 menit, lanjutkan dengan fiksasi pada 120 ${ }^{\circ} \mathrm{C}$ selama 10 menit 
- Tahap fiksasi kitosan pada poliester-selulosa

- buat larutan kitosan masing-masing 0,5\%, $1 \%$ dan $2 \%$ (b/v) sebanyak masing-masing 1 liter, tambahkan masing-masing $250 \mathrm{mg}$ natrium periodat. Pada mesin padding, impregnasi kain yang telah melalui tahap modifikasi poliester pada larutan kitosan, lalu peras diantara 2 rol pemeras untuk mendapatkan WPU 100\% Predrying pada $80{ }^{\circ} \mathrm{C}$ selama 5 menit lanjutkan dengan fiksasi pada $120^{\circ} \mathrm{C}$ selama 10 menit

- Cuci kain yang telah difiksasi kitosan dengan larutan buffer $\mathrm{pH} 5,0$ pada temperatur $40^{\circ} \mathrm{C}$, lalu keringkan

\section{Pengujian}

Pengujian FTIR dilakukan untuk mengetahui terjadinya ikatan kimia antara kitosan dengan serat poliester dan selulosa (kapas, rayon). Pengujian FTIR dilakukan terhadap kain poliester-kapas/rayon yang belum diberi warna (kain grey warna putih), yang difiksasi kitosan yaitu kain hijau $\mathrm{AD}$ dan kain loreng menggunakan FTIR merek Shimadzu Prestige. Untuk mengetahui durabilitas (ketahanan) penempelan kitosan pada kain dilakukan pencucian berulang dengan alat Linitest yang setara dengan 25 kali pencucian rumah tangga. Uji ketahanan bakteri dilakukan dengan menggunakan standar AATCC 147-2004, ${ }^{16}$ Pengujian antibakteri dilakukan terhadap 2 jenis bakteri yaitu bakteri escherichia coli (E.Coli) sebagai bakteri gram negatif dan bakteri staphylococcus aureus (S.Aureus) sebagai bakteri gram positif, dengan menghitung reduksi pertumbuhan bakteri menggunakan persamaan 1 .
Pengujian antibakteri:

$$
\% \mathrm{R}=100 \frac{(\mathrm{A}-\mathrm{B})}{\mathrm{A}}
$$

$\% \mathrm{R}=\%$ Reduksi pertumbuhan bakteri

A $=$ Jumlah bakteri yang tumbuh pada sampel kain, diinkubasi 0 jam

$\mathrm{B}=$ Jumlah bakteri yang tumbuh pada sampel kain setelah diinkubasi selama 24 jam

Uji ketuaan warna dilakukan dengan cara CIE Lab: D65-10. ${ }^{17}$ Dilakukan pengukuran \%R kain pada 400-700 nm. Perhitungan kuantitatif ketuaan warna dilakukan dengan menggunakan persamaan Kubelka Munk (persamaan 2) untuk menghitung $\mathrm{K} / \mathrm{S}$.

$$
\frac{\mathrm{K}}{\mathrm{S}}=\frac{(1-\mathrm{R})^{2}}{2 \mathrm{R}}-\frac{\left(1-\mathrm{R}_{0}\right)^{2}}{2 \mathrm{Ro}}
$$

untuk:

$$
\begin{aligned}
\mathrm{K} / \mathrm{S}= & \text { Konstanta Kubelka Munk } \\
\mathrm{K}= & \text { Koefisien absorpsi } \\
\mathrm{S}= & \text { Koefisien penghamburan cahaya } \\
\mathrm{R}= & \text { Reflektansi kain berwarna pada panjang } \\
& \text { gelombang optimum (pada panjang } \\
& \text { gelombang yang memberikan nilai } \\
& \text { absorbansi maksimum) }
\end{aligned}
$$

\section{Kode hasil penelitian}

Tabel 1. menunjukkan kode sampel dalam penelitian. Sampel dibedakan berdasarkan konsentrasi larutan kitosan yang digunakan dan tahapan proses yang dilakukan.

Tabel 1. Kode Sampel

\begin{tabular}{ccccc}
\hline $\begin{array}{c}\text { Kode } \\
\text { sampel }\end{array}$ & $\begin{array}{c}\text { Jenis } \\
\text { kain }\end{array}$ & Warna kain & $\begin{array}{c}\text { Konsentrasi larutan } \\
\text { kitosan, } \mathbf{\%} \text { b/v }\end{array}$ & $\begin{array}{c}\text { Cuci berulang } \\
\text { Ya/Tidak }\end{array}$ \\
\hline Go & PK & Putih & 0,0 & Tidak \\
\hline G1 & PK & Putih & 0,5 & Tidak \\
\hline G2 & PK & Putih & 1,0 & Tidak \\
\hline G3 & PK & Putih & 2,0 & Tidak \\
\hline Lo & PK & Loreng & 0,0 & Tidak \\
\hline L1 & PK & Loreng & 0,5 & Tidak \\
\hline L2 & PK & Loreng & 1,0 & Tidak \\
\hline L3 & PK & Loreng & 2,0 & Ya \\
\hline CL1 & PK & Loreng & 0,5 & Ya \\
\hline CL2 & PK & Loreng & 1,0 & Ya \\
\hline CL3 & PK & Loreng & 2,0 & Tidak \\
\hline Ho & PR & Hijau AD & 0,0 & Tidak \\
\hline H1 & PR & Hijau AD & 0,5 & Tidak \\
\hline H2 & PR & Hijau AD & 1,0 & Tidak \\
\hline H3 & PR & Hijau AD & 2,0 & Ya \\
\hline CH1 & PR & Hijau AD & 0,5 & Ya \\
\hline CH2 & PR & Hijau AD & 1,0 & Ya \\
\hline CH3 & PR & Hijau AD & 2,0 & \\
\hline PK
\end{tabular}

Ket: PK=poliester-kapas; PR=poliester-rayon; cuci berulang=pencucian 5 kali (setara pencucian rumah tangga 25 kali) 


\section{HASIL DAN PEMBAHASAN}

\section{Hasil uji FTIR}

Data hasil uji FTIR disajikan pada Gambar 3 berupa kain $\mathrm{G}_{0}$ (kain grey warna putih tanpa kitosan), pada Gambar 4 berupa kain G3 (kain grey warna putih dengan kitosan 2\% b/v), Gambar 5, berupa perbandingan spektra IR kain Hijau AD tanpa kitosan tanpa cuci berulang (Ho), kain Hijau $\mathrm{AD}$ dengan kitosan $2 \% \mathrm{~b} / \mathrm{v}$ tanpa cuci berulang (H3) dan kain Hijau AD dengan kitosan 2\% b/v dengan cuci berulang (CH3).

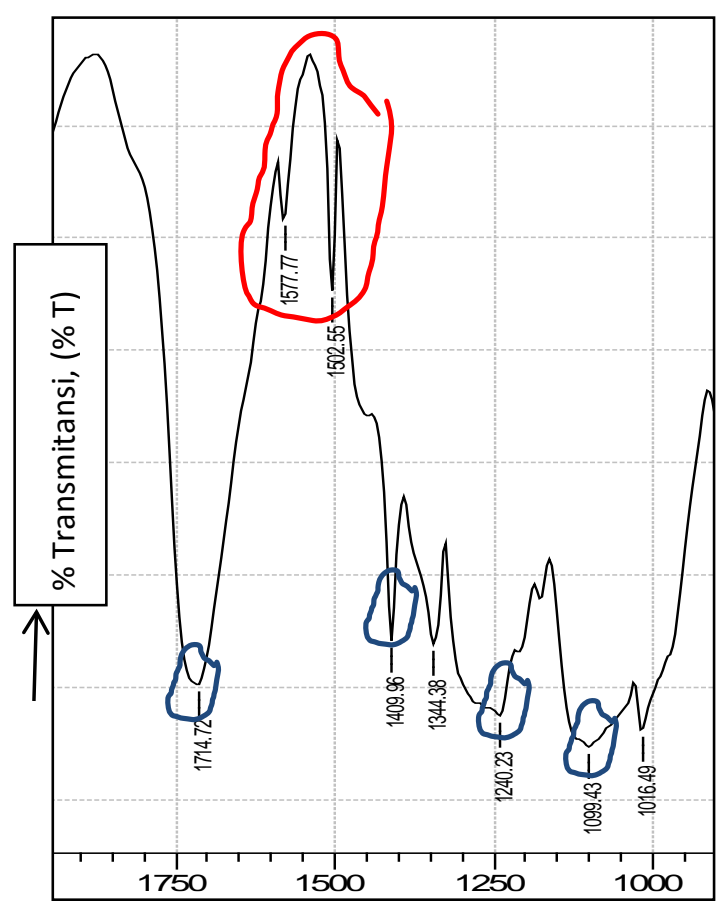

Bilangan gelombang $\mathrm{v}, \overline{\mathrm{cm}}^{-1}$

Gambar 3. Spektra IR kain G0

Dari penelitian terdahulu, ${ }^{13,18-19}$ analisa FTIR kain kapas fiksasi kitosan menunjukkan puncakpuncak, yaitu pada bilangan gelombang 3300 $3500 \mathrm{~cm}^{-1}$ untuk gugus $\mathrm{OH}^{-}$dan $\mathrm{NH}_{2}$, serta 1325 $\mathrm{cm}^{-1}$ juga untuk amina ; $1730 \mathrm{~cm}^{-1}$ lemah dari stretching vibrasi $\mathrm{C}=\mathrm{O}$ dari gugus aldehid; dan $1641 \mathrm{~cm}^{-1}$ untuk gugus $\mathrm{C}=\mathrm{N}$ yang terbentuk antara aldehid dan kitosan yang menunjukkan terjadinya fiksasi kitosan pada kain kapas tersebut.

Poliester yang merupakan polimer sintetis dari asam tereftalat dan etilen glikol, dengan FTIR akan memberikan puncak-puncak pada bilangan gelombang 1750 - $1725 \mathrm{~cm}^{-1}$ untuk stretching vibrasi $\mathrm{C}=\mathrm{O}$ pada gugus ester, pada $1300-1000$ $\mathrm{cm}^{-1}$ untuk stretching vibrasi C-O. ${ }^{20}$ Dari penelitian terdahulu, ${ }^{14}$ kain poliester-selulosa setelah fiksasi kitosan menunjukkan puncak-puncak pada posisi bilangan gelombang $1714 \mathrm{~cm}^{-1}$ untuk stretching vibrasi $\mathrm{C}=\mathrm{O}$ dalam gugus ester, pada $1240 \mathrm{~cm}^{-1}$ dan $1097 \mathrm{~cm}^{-1}$ untuk stretching vibrasi C-O, sedangkan stretching vibrasi $\mathrm{C}=\mathrm{N}$ terlihat dari puncak pada bilangan gelombang $1409 \mathrm{~cm}^{-1}$. Hal ini sesuai dengan yang ditunjukkan pada Gambar 4.

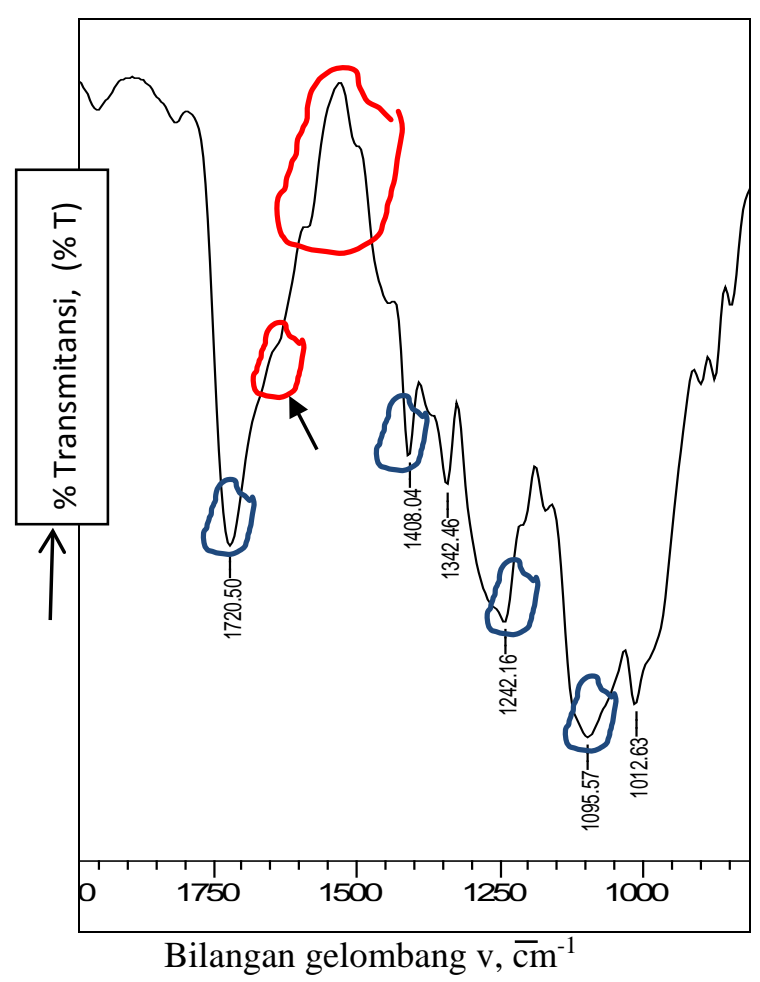

Gambar 4. Spektra IR kain G3

Pada Gambar 3 dan 4, lingkaran biru dan merah menunjukkan puncak yang diamati. Dari Gambar 3 (kain $\mathrm{G}_{0}$ ) dan Gambar 4 (kain G3 yaitu kain $\mathrm{G}_{0}+$ kitosan) terlihat bahwa kain $\mathrm{G}_{0}$ dan kain G3 memberikan puncak-puncak yang sama (lingkaran biru) yaitu pada bilangan gelombang $1409 \mathrm{~cm}^{-1}$ dari vibrasi $\mathrm{C}=\mathrm{N}$, puncak pada bilangan gelombang $1263 \mathrm{~cm}^{-1}$ dan $1097 \mathrm{~cm}^{-1}$ untuk stretching vibrasi $\mathrm{C}-\mathrm{O}, 1712 \mathrm{~cm}^{-1}$ dari vibrasi $\mathrm{C}=\mathrm{O}$ dalam gugus ester. Pada kain G3 (lingkaran merah) terdapat tambahan puncak yang lemah pada $1640 \mathrm{~cm}^{-1}$ untuk gugus $\mathrm{C}=\mathrm{N}$ yang terbentuk antara aldehid dan kitosan yang menunjukkan terjadinya fiksasi kitosan pada kapas, dan perbedaan pada daerah $1560 \mathrm{~cm}^{-1}$ dari bending $\mathrm{NH}$ pada grup amina. ${ }^{20}$

Pada Gambar 5. disajikan perbandingan spektra IR kain Ho, H3 dan CH3, terlihat bahwa kain Ho, H3 dan CH3 memberikan puncak pada posisi bilangan gelombang yang sama, yang merupakan overlapping gugus-gugus yang ada pada kitosan, kapas dan poliester yaitu pada bilangan gelombang $1409 \mathrm{~cm}^{-1}$ dari vibrasi $\mathrm{C}=\mathrm{N}$, pada bilangan gelombang $1240 \mathrm{~cm}^{-1}$ dan $1097 \mathrm{~cm}^{-1}$ dari vibrasi C-O, dan pada bilangan gelombang 1718 $\mathrm{cm}^{-1}$ dari vibrasi $\mathrm{C}=\mathrm{O}$ dalam gugus ester. 


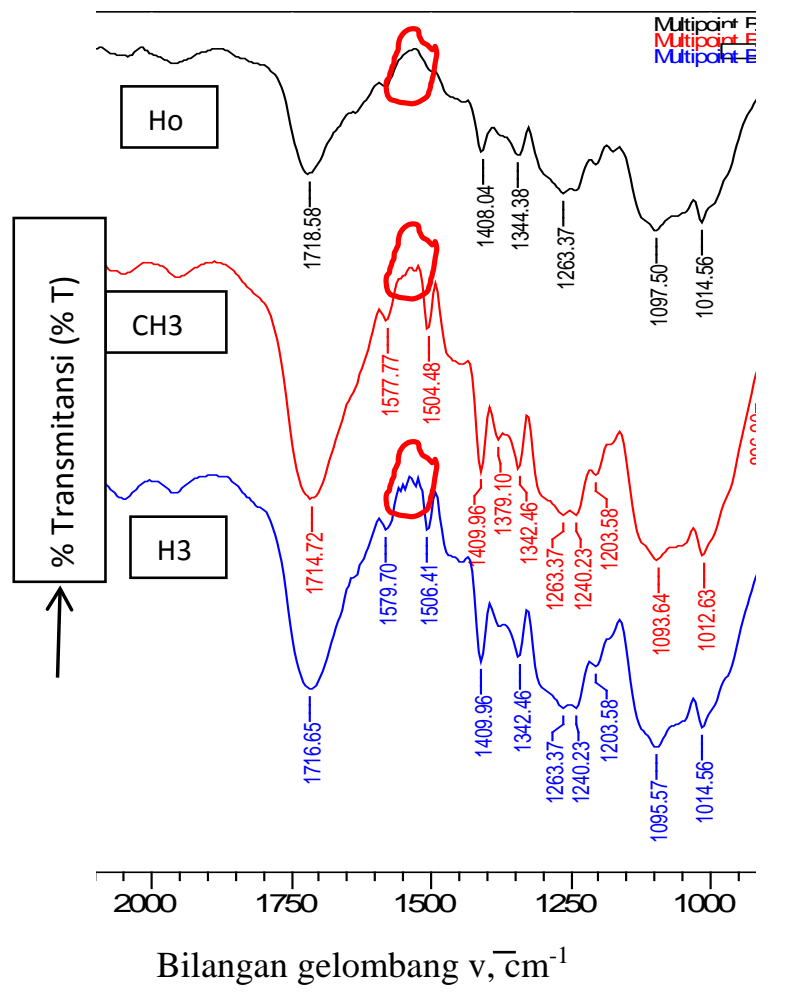

Pada Gambar 5. terdapat perbedaan pada daerah $1560 \mathrm{~cm}^{-1}$ (lingkaran merah) dari bending $\mathrm{NH}$ pada grup amina, ${ }^{21}$ di daerah tersebut pada kain H3 dan kain CH3 terlihat adanya puncak walaupun lemah tetapi tidak terlihat pada kain Ho. Walaupun lemah, hal ini memberi indikasi bahwa kitosan dengan gugus -NH2 sebagai gugus aktifnya telah berikatan dengan poliester-rayon (selulosa). Fiksasi kitosan pada kain H3 mempunyai durabiliti yang baik, terlihat dari puncak pada kain $\mathrm{CH} 3$ yang relatif sama dengan kain $\mathrm{H} 3$.

Dari uji FTIR memberi indikasi bahwa cara padding dengan modifikasi poliester berhasil menempelkan kitosan pada kain poliester-selulosa yang belum diberi warna (kain gray) maupun yang telah diberi warna (kain hijau). Pembuktian dengan uji FTIR untuk terbentuknya ikatan antara kitosan dengan kapas dan poliester perlu diperkuat dengan uji ketahanan bakteri, karena adanya kitosan pada kain akan memberikan sifat ketahanan bakteri pada kain. Hasil uji ketahanan bakteri disajikan pada Gambar 6.

Gambar 5. Perbandingan spektra IR kain hijau AD, Ho, H3 dan CH3

\section{Hasil uji ketahanan bakteri}

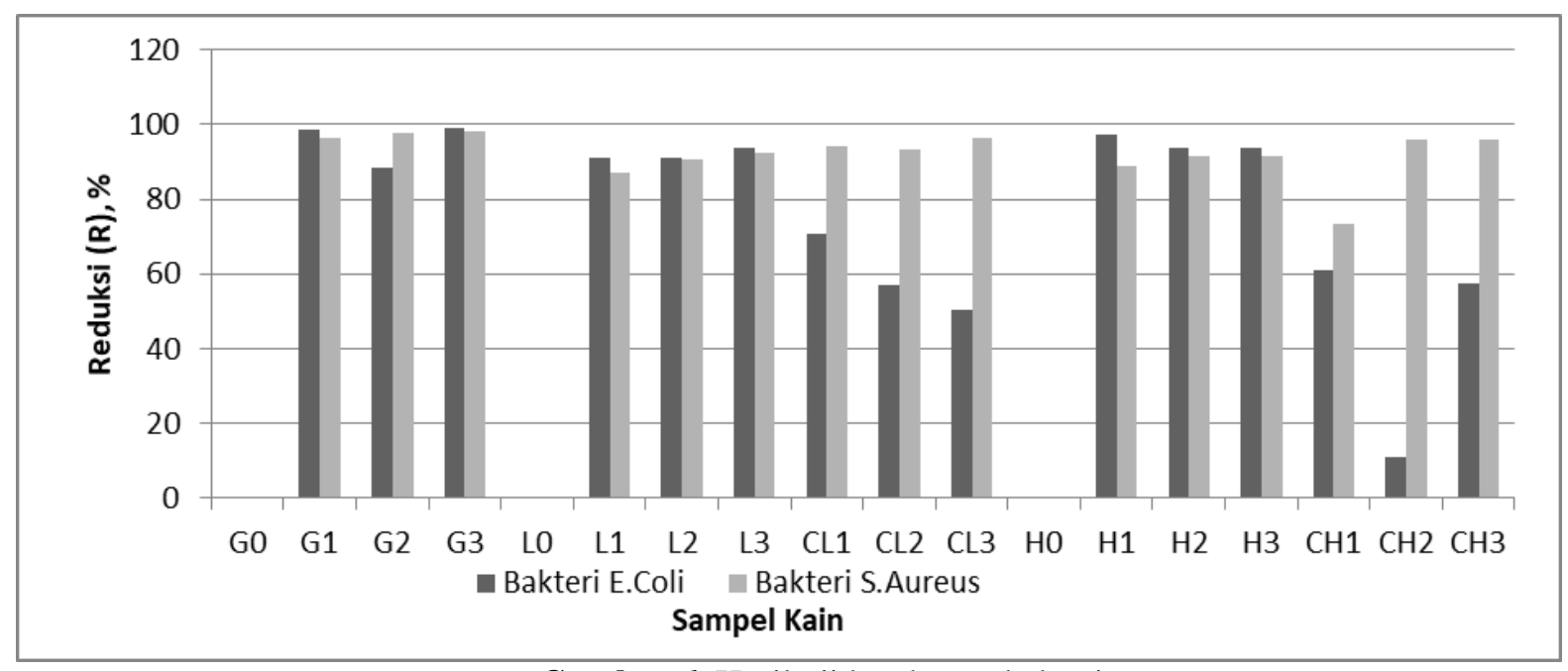

Gambar 6. Hasil uji ketahanan bakteri

Uji ketahanan bakteri dilakukan terhadap kain poliester-kapas/rayon yang tidak dibubuhi kitosan (kain $\mathrm{G}_{0}, \mathrm{~L}_{0}$ dan $\mathrm{H}_{0}$ ), dan yang telah dibubuhi kitosan belum diberi warna (kain G1, G2, G3), diberi warna loreng (L1, L2, L3) dan hijau AD (kain H1, H2, H3), serta kain loreng dan hijau AD yang telah mengalami pencucian berulang (CL1, CL2, CL3 dan CH1, CH2, CH3), dengan melihat reduksi bakteri yang diberikan setelah inkubasi selama 24 jam yang dihitung menurut persamaan
(1). Hasil uji ketahanan bakteri disajikan pada Gambar 6.

Dari Gambar 6, terlihat bahwa ketahanan terhadap bakteri E. Coli, untuk kain yang tidak dibubuhi kitosan (Go, Lo dan Ho) reduksi nya $0 \%$ dan data menunjukkan pada kain $\mathrm{G}_{0}$ dan $\mathrm{L}_{0}$ terjadi pertumbuhan/peningkatan jumlah bakteri 2 dan 10 kali lipat. Kain yang belum diberi warna dibubuhi kitosan (kain G1, G2, G3) dan yang telah diberi warna loreng dan hijau AD (L1, L2, L3 dan H1, H2, H3) memberikan reduksi 90-98\%. Hal ini 
menunjukkan bahwa pemberian kitosan dengan teknik padding pada kain poliester-selulosa yang belum diberi warna maupun telah diberi warna telah berhasil menempelkan kitosan pada kain- kain tersebut sehingga memberikan sifat tahan bakteri E.Coli pada kain. Setelah pencucian berulang (CL1, CL2, CL3 dan CH1, CH2, CH3) reduksi menurun hingga tinggal $50-70 \%$ atau turun $20-40 \%$ tetapi anomali pada kain $\mathrm{CH} 2$.

Ketahanan terhadap bakteri S.Aureus, untuk kain yang tidak dibubuhi kitosan (kain $\mathrm{G}_{0}, \mathrm{~L}_{0}$ dan $\mathrm{H}_{0}$ ) reduksi nya $0 \%$. Kain yang belum diberi warna dibubuhi kitosan (kain G1, G2, G3) dan yang telah diberi warna loreng dan hijau (L1, L2, L3 dan H1, H2, H3) memberikan reduksi 90-98\%. Hal ini menunjukkan bahwa pemberian kitosan dengan teknik padding pada kain poliester-selulosa yang belum diberi warna maupun telah diberi warna telah berhasil menempelkan kitosan pada kain- kain tersebut sehingga memberikan sifat tahan bakteri S.Aureus pada kain. Setelah pencucian berulang (CL1, CL2, CL3 dan CH1, CH2, CH3) reduksi menurun hingga tinggal $70-90 \%$ atau turun $0-20 \%$.

Dari Gambar 6, terlihat pengaruh penambahan konsentrasi kitosan dalam larutan padding yaitu 0,5\%, 1,0\% serta 2,0\% terhadap ketahanan bakteri kain gray , loreng dan hijau AD yang telah dibubuhi kitosan untuk bakteri E.Coli diperoleh walaupun perbedaannya cukup kecil bisa menaikkan atau menurunkan ketahanan bakteri E.Coli, sedangkan untuk bakteri S. Aureus walaupun cukup kecil terlihat makin besar konsentrasi kitosan dalam larutan padding akan sedikit menaikkan ketahanan bakteri (\% reduksi sedikit meningkat).

\section{Hasil uji ketuaan warna}

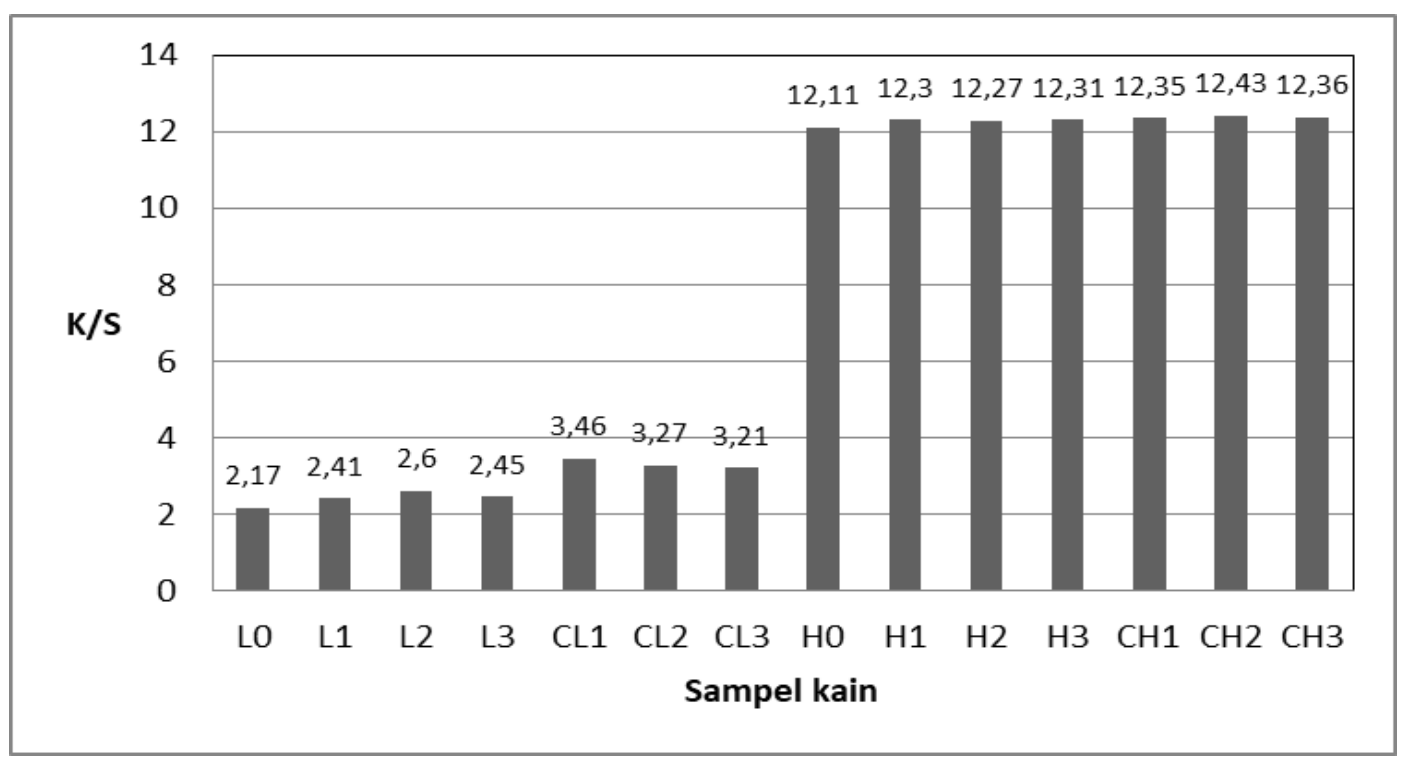

Gambar 7. Hasil uji ketuaan warna

Untuk mengetahui pengaruh pemberian kitosan terhadap warna kain dilakukan pengujian ketuaan warna yang direpresentasikan dengan nilai $\mathrm{K} / \mathrm{S}$ untuk nilai K/S yang makin tinggi menunjukkan warna yang makin tua. Pengujian ketuaan warna dilakukan dengan membuat kurva reflektansi \%R (\% reflektansi) terhadap panjang gelombang $(\lambda)$ pada $400 \mathrm{~nm}-700 \mathrm{~nm}$. Dilakukan pengukuran \%R untuk kain hijau Ho, H1, H2, H3, $\mathrm{CH} 1, \mathrm{CH} 2, \mathrm{CH} 3$ dan warna krem pada loreng Lo, L1, L2, L3, CL1, CL2, CL3

Dari kurva reflektansi masing-masing kain diambil nilai \%R untuk setiap sampel kain pada panjang gelombang $(\lambda)$ optimum, kemudian dihitung nilai $\mathrm{K} / \mathrm{S}$ menggunakan persamaan Kubelka Munk (Persamaan 2), hasilnya disajikan pada Gambar 7.

Dari Gambar 7. terlihat bahwa pada kain loreng (poliester-kapas 65:35) yaitu Lo, L1, L2, L3, pemberian kitosan dengan konsentrasi $(0,5 \%$ 2,0\%) pada larutan padding, telah menaikkan nilai K/S 11\%-19\% berarti ketuaan warna tidak menurun malah terjadi peningkatan ketuaan warna, Setelah pencucian berulang, (CL1, CL2, CL3) nilai K/S sedikit naik lagi. Hal ini diduga dari adanya kitosan yang memberi sifat kationisasi pada kapas memperkuat ikatan kapas dengan zat warna reaktif. ${ }^{22}$ Demikian pula untuk kain hijau (Ho, H1, H2, H3) pemberian kitosan dengan konsentrasi $(0,5 \%-2,0 \%)$ pada larutan padding, menaikankan nilai $\mathrm{K} / \mathrm{S}$ 1,3\%-1,6\% berarti ketuaan warna tidak menurun. Setelah pencucian berulang, (CH1, CH2, CH3) nilai K/S sedikit naik lagi. Secara visual, perubahan warna yang terjadi masih berada dalam batas toleransi perbedaan warna yang terlihat secara visual. 


\section{KESIMPULAN}

Melalui 2 tahap proses modifikasi gugus poliester-selulosa yaitu proses untuk menempelkan gugus amina dari alkilamina (dodesilamina) pada serat poliester dilanjutkan dengan proses untuk oksidasi selulosa dengan periodat yang menghasilkan gugus aldehida bersamaan dengan menempelkan kitosan pada serat poliester-selulosa termodifikasi, telah dihasilkan kain poliesterkapas/rayon yang mempunyai sifat antibakteri. Proses penempelan dilakukan dengan teknik padding 2 tahap. Sifat antibakteri yang diperoleh mempunyai durabilitas (ketahanan) terhadap pencucian yang baik yaitu setelah pencucian berulang setara 25 kali pencucian rumah tangga, ketahanan terhadap bakteri S.Aureus hampir tidak berubah yaitu turun $0-20 \%$, sedangkan terhadap bakteri Escherichia coli ketahan bakteri turun sebanyak $20-40 \%$. Penempelan kitosan dengan cara padding 2 tahap pada kain poliester-kapas/rayon berwarna, walaupun memberikan peningkatan atau penurunan nilai $\mathrm{K} / \mathrm{S}$, tetapi secara visual tidak mengakibatkan perubahan ketuaan warna yang signifikan.

\section{PUSTAKA}

1. Joshi, M., Ali, S. W., \& Purwar, R. Ecofriendly Antimicrobial Finishing of Textiles using Bioactive Agent Based on Natural Products. Indian Journal of Fiber \& Textiles Research 34, 295-304 (2009).

2. Dhillon, G.S., Kaur, S., Sarma, S.J., Brar, S.K., Verma, M., \& Surampalli, R.Y. Recent Development in Applications of Important Biopolymer Chitosan in Biomedicine.

3. Prashanth, K.V.H. \& Tharanathan, R.N. Chitin/chitosan: Modifications and Their Unlimited Application Potential-An Overview, Trens in Food Science \& Technology 18, 117-131 (2007).

4. Mohanasrinivasan, V., et. al . Study on Heavy Metal Removal Efficiency and Antibacterial Activity of Chitosan Prepared from Shrimp Shell Waste, Springerlink.com open access (2013).

5. Liu, N., et.al. Effect of MW and Concentration of Chitosan on Antibacterial Activity of Escherichia coli, Carbohydrate Polymers 64, 60-65 (2006).

6. Yu, Y., McQueen, R., \& Wismer, W. A Priliminary Study on Collection and Detection of Axyllary Odor within Textiles. Journal of Textile and Apparel Technology and Management 8, 113 (2013).

7. Liu, S., \& Sun, G. Bio-functional Textiles. In V.T.Bartels (Eds.), Handbook of Medical
Textiles, 336-359 (2011). Woodhead Publishing Limited

8. Ibrahim, N.A. \& Hashem, M. Enhanching Antimicrobial Properties of Dyed and Finished Cotton/Polyester Fabrics, AATCC Review, 56-64 (2010).

9. Gao Y., \& Cranston R. Recent Advances in Antimicrobial Treatment of Textiles,.Textile Research Journal 78 (1), 60-72 (2008).

10. Ashraf, M., Dumont, F., Campagne, C., Champagne, P., Perwuelz, A., Lerich, A., et.al., Development of Antibacterial Polyester Fabric by Growth of $\mathrm{ZnO}$ Nanorods. Journal of Engineered Fibers and Fabrics 9 (1), 15-22 (2014)

11. Chattopadhyay, D., \& Inamdar, M.S. Improvement in Properties of Cotton Fabrics through Synthesized Nano-Chitosan Application. Indian Journal of Fibre \& Textile Research 38, 14-21 (2013)

12. Ramadan, M.A., Samy, S., Abdulhady, M., \& Hebeish, A.A. Eco-Friedly Pretreatment of Cellulosic Fabrics with Chitosan and Its Influence on Dyeing Efficiency, Natural Dyes. Emiye Akcakola Kumbasar (Ed.), In Tech (2011).

13. Winiati, W., Kasipah, C., Yulina, R., Wahyudi, T., Mulyawan, A.S., \& Septiani, W. Fiksasi Kitosan pada Kain Kapas sebagai Antibakteri. Arena Tekstil 29 (1), 25-36 (2014).

14. Winiati, W., Kasipah, C., Septiani, W., Novarini, E., \& Yulina, R. Aplikasi Kitosan sebagai Zat Antibakteri pada Kain Poliester-Selulosa dengan Cara Perendaman. Arena Tekstil 31 (1), 1-10 (2016).

15. Knittel, D., Schollmeyer, E. Chitosan for Permanent Antimicribial Finish on Textile, Lenzinger Berichte 85, 124-130 (2006).

16. AATCC Test Method 147-1998, Antibacterial Activity Assessment of Textile Materials, AATCC Technical Manual (2004).

17. Anonim. Color iQC and Color iMatch, Color Calculation Guide. Versi 8.0, July 2012.

18. Rajendran, R., Radhai, R., Balakumar, C., Ahamed, H.M., Vigneswaran, C., Vaideki, K. Synthesis and Characterization of Neem Chitosan Nanocomposites for Development of Antimicrobial Cotton Textiles. Journal of Engineered Fibers and Fabrics 7 (1), 136-141 (2012)

19. Shanmugasundaran, O.L. Chitosan Coated Cotton Yarn and It's Effect on Antimicrobial Activity, 
Aplikasi Kitosan sebagai Zat Antibakteri pada Kain Poliester-Selulosa dengan Cara Modifikasi Gugus Poliester-Selulosa (Wiwin Winiati, dkk.)

Journal of Textile Apparel Technology and Management 5 (3), 1-6 (2006).

20. Silverstein, R. M., Webster, F. X., Kiemle, D. J. Spectrometric Identification of Organic Compounds . $7^{\text {th }}$ edition. John Wiley \& Sons (2005).

21. Periolatto, M., Ferrero, F. Cotton Filter Fabrics Functionalization by Chitosan UV-grafting for
Removal of Dyes. Chemical Engineering Transactions 32, 85-90 (2013)

22. Kasipah,C., Novarina, E., Rakhmatiara, E.M., Natawijaya, D. Peningkatan Kemampuan Pencelupan Kain Kapas terhadap Zat Warna Reaktif melalui Proses Kationisasi. Arena Tekstil 30 (2), 55-66 (2015). 
Arena Tekstil Vol. 32 No. 2, 2017: 93-102 